\title{
Productivity and Nutrient Content of the Second Regrowth Alfalfa (Medicago Sativa L.) with Different Photoperiod and Dolomite
}

\author{
Bambang Suwignyo*, Fransiskus Xaverius Dika Kurniawan, Nilo Suseno, Ristianto Utomo and Bambang \\ Suhartanto
}

Faculty of Animal Science, Universitas Gadjah Mada, Yogyakarta, Indonesia

*Corresponding author email: bsuwignyo@ugm.ac.id

\begin{abstract}
The study was conducted to identify the effect of lighting duration and dolomite addition on the vegetative growth of alfalfa plants in second regrowth phase. The experiment was conducted in the greenhouse of the Laboratory of Forage and Pasture Science, Faculty of Animal Science, Universitas Gadjah Mada. It used a completely randomized design with $3 \times 3$-factorial using two factors and three replications. The first factor was lighting duration (C) with 3 levels ( $C 0=12$ hours, $C 1=14$ hours, and $C 2=16$ hours). The second factor was dolomite addition (D) with 3 levels ( $D 0=0$ ton/ha, D1 = 6 ton $/$ ha, and D2 = 12 ton/ha). The results showed a significant effect so Duncan Multiple Range Test (DMRT) followed at $5 \%$ and $1 \%$ levels. The observed variables were plant height, the number of plant branches, the number of plant leaves, fresh forage production, and the chemical content of the plants in the form of dry matter (DM) and organic matter (OM). The addition of dolomite significantly affected the number of the plant branches, the number of plant leaves and the dry matter of the plants. A significant correlation was found between the two treatments and the number of leaves (C2D2) and a correlation was between the treatment and dry matter (C1D2).
\end{abstract}

Keywords: dolomite, lighting duration, plant branches, leaves number, vegetative growth

Abstrak. Penelitian ini bertujuan untuk mengetahui pengaruh penambahan lama pencahayaan dan dolomit terhadap pertumbuhan vegetatif tanaman alfalfa pada fase regrowth kedua. Penelitian dilakukan di rumah kaca Laboratorium Ilmu Hijauan Makanan Ternak dan Pastura, Fakultas Peternakan, Universitas Gadjah Mada. Penelitian ini menggunakan Rancangan Acak Lengkap Pola Faktorial 3x3. Perlakuan pertama adalah lama pencahayaan (C) 3 taraf yakni $\mathrm{CO}=12 \mathrm{jam}, \mathrm{C} 1=14 \mathrm{jam}, \mathrm{C} 2=16 \mathrm{jam}$. Perlakuan kedua adalah penambahan dolomit (D) 3 taraf yakni D0= 0 ton/ha, D1= 6 ton/ha, D2= 12 ton/ha. Hasil yang berbeda nyata dilakukan uji lanjutan dengan Duncan Multiple Range Test (DMRT) pada taraf $5 \%$ dan $1 \%$. Variabel yang diamati adalah tinggi tanaman, jumlah cabang tanaman, jumlah daun tanaman, produksi hijauan segar dan kandungan kimia tanaman berupa bahan kering (BK) dan bahan organik (BO). Hasil penelitian menunjukkan bahwa lama pencahayaan berpengaruh nyata terhadap tinggi tanaman jumlah cabang tanaman. Penambahan dolomit berpengaruh nyata terhadap jumlah cabang, jumlah daun tanaman dan bahan kering tanaman. Terdapat interaksi antara dua perlakuan terhadap jumlah daun yaitu pada perlakuan lama pencahayaan 16 jam dan penambahan dolomit 12 ton/ha (C2D2) dan interaksi perlakuan terhadap bahan kering pada perlakuan lama pencahayaan 14 jam dan penambahan dolomit 12 ton/ha (C1D2).

Kata kunci: dolomit, lama pencahayaan, cabang tanaman, jumlah daun pertumbuhan vegetatif

\section{Introduction}

Forage plays an important role for ruminant. Alfalfa as a forage plant has a high crude protein content from 16.0 to $29.1 \%$ (Sajimin, 2011) and can serve as quality forage source. Many folk medicines have been using the seeds for its lactigenic properties (Abdulwehab et al., 2015). The alfalfa has been commonly grown in various subtropical countries, so it is rarely grown in Indonesia. It is necessary to give special treatments so that it can grow in a condition close to its original environment
(Suwignyo et al., 2017). Alfalfa/ Lucerne grows in many parts of subtropics and warm temperate regions as 'the most widely adapted agronomic crop'. Having the highest feeding value, the plant is the most treasured forage legume.

Solar radiation over Indonesia in the tropical area in equatorial zone lasts for 12 hours, meanwhile, alfalfa is a long day plant that requires sun light for more than 14 hours (Cash, 2009). The radiation, the quality, the intensity and the duration of the sunlight are the 
influencing factors of the growth and the development of the plant.

Growth is the key determinant factor of forage production quality as the plant is harvested, while its dry matter continuously increases from the beginning of its growth until its flowering phase (Smith et al., 2006). The other supporting factor of the growth of the alfalfa is sufficient calcium content $(\mathrm{pH} 6.5)$ or good soil fertility (Widyati et al., 2012). Soil calcification can be conducted by adding dolomite. Suwignyo et al. (2017) informed that dolomite can be used in regosol soil as the source of calcium and magnesium. Similarly, Gardner et al. (1991) suggest that dolomite represent a limestone from the secondary mineral sediment rich in calcium and magnesium ( $\mathrm{Ca} \mathrm{Mg}$ (CO3)2). Alfalfa can grow optimally at pH 6.0 to 6.5 (Subantoro, 2009) and survive the long dry season (Sajimin, 2011) at an optimal temperature range from $20^{\circ} \mathrm{C}$ to $30^{\circ} \mathrm{C}$ (Fitter and Hay, 1981). Accordingly, it is vital to investigate the characteristics of the vegetative growth of the alfalfa in tropical area such as regrowth, lighting and dolomite addition.

\section{Materials and Methods}

\section{Study area}

The study was conducted from December 2017 to February 2018 in the greenhouse of the Laboratory of Forage and Pasture Science, Faculty of Animal Science, Univesitas Gadjah Mada. The instruments included polybags of 45 x $45 \mathrm{~cm}$, mulch plastic, sprayers, Philips 36 watt cool daylight neon, thermometer, switch timer, a $55^{\circ} \mathrm{C}$ oven, Wiley mill ( $1 \mathrm{~mm}$ screen), a $105{ }^{\circ} \mathrm{C}$ oven, furnace, silica disk, desiccator and crucible.

\section{Method}

The study was conducted in a completely randomized 3x3-factorial design with 2 treatmens. The first treatment was dolomite addition (D) consisting of DO = without any dolomite addition ( $0 \mathrm{~g} /$ polybag or 0 ton/ha), D1 $=$ the dolomite adition of $90 \mathrm{~g} /$ polybag or 6 tons/ha, and D2 = the dolomite adition of 180 $\mathrm{g} /$ polybag or 12 tons/ha.

The second treatment was lighting duration (C) consisting of:

$\mathrm{CO}=$ the lighting addition for 0 hour ( 12 hous),

C1 = the lighting addition for 2 hours (14 hours), and

$\mathrm{C} 2=$ the lighting addition for 4 hours (16 hours).

The two factors gave 9 treatment combinations as presented in Figure 1. Meanwhile, the treatment layout with 4 replications resulted in 36 experimental units.

CODO = the lighting duration of 12 hours and the dolomite addition of 0 ton/ha,

C1D0 $=$ the lighting duration of 14 hours and the dolomite addition of 0 ton/ha,

C2DO = the lighting duration of 16 hours and the dolomite addition of 0 ton/ha,

COD1 = the lighting duration of 12 hours and the dolomite addition of 6 tons/ha,

C1D1 = the lighting duration of 14 hours and the dolomite addition of 6 tons/ha,

C2D1 = the lighting duration of 16 hours and the dolomite addition of 6 tons/ha,

COD2 = the lighting duration of 12 hours and the dolomite addition of 12 tons/ha,

C1D2 = the lighting duration of 14 hours and the dolomite addition of 12 tons/ha, and

C2D2 = the lighting duration of 16 hours and the dolomite addition of 12 tons/ha. 


\begin{tabular}{|c|c|c|c|c|c|c|c|c|}
\hline C2D0-1 & C2D1-2 & C2D2-4 & C1D0-4 & C1D1-2 & C1D2-4 & CODO-1 & COD1-3 & COD2-4 \\
\hline C2DO-3 & Cי201-1 & C20-3 & c1no-3 & C1D1-1 & C10 & cenn-2 & con1-2 & con?-2 \\
\hline & & & & & & & & \\
\hline C2D0-4 & C2D1-4 & C2D2-1 & C1D0-2 & C1D1-4 & C1D2-3 & CODO-3 & COD1-1 & COD2-3 \\
\hline C2D0-2 & C2D1-3 & C2D2-2 & C1D0-1 & C1D1-3 & C1D2-1 & CODO-4 & C0D1-4 & COD2-1 \\
\hline
\end{tabular}

Figure 1 . The study treatment layout with 4 replicaiton

\section{The Implementation of the Study}

The growing media used in the study was regosol soil of the forage land of the Faculty of Animal Science, Universitas Gadjah Mada. The media was prepared by mixing a kilogram regosol soil and a kilogram green manure (1:1) and the dolomite was incorporated to the mixed soil according to the treatments $(0,6$, and 12 tons/ha). Before planting, the growing media was watered for 6 days to maintain the soil moisture.

Prior to planting, the seeds were tested by soaking in water; the sinking ones were selected and sown (Sarmita et al., 2011). The seeds were sown on the day 6 by directly sowing them in the prepared polybag. Three holes of $2 \mathrm{~cm}$ of depth were made on the soil surface in the polybag and then 3 seeds (from Canada) were filled into each of the holes and covered with soil.

The treatment of the lighting duration consisted of: $\mathrm{CO}$, which was sun lighting for 12 hours and without any neon light lighting; $\mathrm{C} 1$, which was sun lighting for 12 hours with 2 neon lights lighting (14 hours); and C2, which was sun lighting for 12 hours with 4 neon lights lighting (16 hours). The addition of the lighting was conducted using Philips 36 watt neon cool daylight light that was fixed $1.5 \mathrm{~m}$ above ground.

The plants were watered twice a day in the morning and evening, and thinned 2 weeks after sowing by keeping three that grew well.
Pests and diseases were mechanically managed by removing the pests on the plants, such as caterpillar and grasshopper. At the time of morning watering (at 06.00 a.m.) the partition among the treatments was opened and at the time of evening watering (06.00 p.m.) the partition was closed. Ambient temperature was checked 3 times a day simultaneously with the morning and evening watering with an additional checking at noon (12.00 a.m.).

The first defoliation was conducted 11 weeks after planting and the next defoliation occured 6 weeks after the first one when the flower buds have emerged or when the generative phase began. It was conducted by cutting the parts of the plants that were $5 \mathrm{~cm}$ to $10 \mathrm{~cm}$ above ground (Olroff dan Putnam, 2007).

\section{Variables Measured}

Plant height. The plant height was measured weakly, starting from the first week after defoliation until 6 weeks after defoliation. It was measured from the soil surface in the polybag up to the highest tip of the palnts.

The number of plant branches. The number of the plant branches was counted biweekly until 6 weeks after defoliation. All branches in the main stem were counted.

The number of plant leaves. The number of the plant leaves was counted biweekly until 6 weeks after defoliation. All of the completely opened leaves (trifoliates) of a plant were counted. 
Fresh weight. All parts of the plants harvested from each polybag were weighed to take the fresh weight of the plant (g).

The analysis of dry matter and organic matter content.The analysis of the nutrient content of the plant was performed using AOAC method (2005), including water content (WC), dry matter (DM), organic matter (OM) and ash content as summarized in Appendixes 3 and 4.The growing media used in the study was regosol soil of the forage land of the Faculty of Animal Science, Universitas Gadjah Mada. The media was prepared by mixing a kilogram regosol soil and a kilogram green manure (1:1) and the dolomite was incorporated to the mixed soil according to the treatments $(0,6$, and 12 tons/ha). Before planting, the growing media was watered for 6 days.

\section{Data analysis}

The data were analyzed using a variant analysis with a completely randomized $3 \times 3-$ factorial design. The significantly different results were further analyzed using Duncan multiple range test (DMRT) at the levels of $5 \%$ (Steel and Torrie, 1995) and 1\%.

\section{Results and Discussion}

\section{Overview}

The temperature was observed and measured using a thermometer. The location of the study was the greenhouse of the Laboratory of Forage and Pasture, Faculty of Animal Science, Universitas Gadjah Mada, Yogyakarta. The results showed that the mean temperature was $24^{\circ} \mathrm{C}$ in the morning, $32^{\circ} \mathrm{C}$ at noon and $26.58^{\circ} \mathrm{C}$ in the evening. The ambient temperature of the location of the study was contrary to that by Fitter and Hay (1981) who suggested that alfalfa could grow well at the optimal temperature of $20^{\circ} \mathrm{C}$ to $30^{\circ} \mathrm{C}$.

The growing media in each polybag that was prepared by mixing regosol soil, green fertilizer and dolomite was analyzed before the implementation of the study. Soil analysis was performed in Balai Pengkajian Teknologi Pertanian (BPTP) Yogyakarta. The original soil contained very high carbon (5.32 to $7.69 \%$ ) and high nitrogen $(0.48$ to $0.64 \%)$. The results of mineral test showed that the potential P2O5 $p$ was 210 to $250 \mathrm{mg} / 100 \mathrm{~g}$, and $\mathrm{K} 2 \mathrm{O}$ was 37 to 48 $\mathrm{mg} / 100 \mathrm{~g}$. Table 2 summarizes the soil analysis result before the study implementation.

Table 2. The soil analysis result before study implementation

\begin{tabular}{lcccc}
\hline \multirow{2}{*}{ Treatment } & \multicolumn{4}{c}{ Test Parameters } \\
\cline { 2 - 5 } & Organic-C (\%) & Total-N (\%) & Potential $\mathrm{P}_{2} \mathrm{O}_{5}(\mathrm{mg} / 100 \mathrm{~g})$ & Potential $\mathrm{K}_{2} \mathrm{O}(\mathrm{mg} / \mathbf{1 0 0 \mathrm { g } )}$ \\
\hline COD0 & 7.69 & 0.64 & 239 & 39 \\
COD1 & 6.41 & 0.48 & 221 & 37 \\
COD2 & 6.22 & 0.51 & 230 & 39 \\
C1D0 & 6.94 & 0.55 & 250 & 41 \\
C1D1 & 7.09 & 0.61 & 249 & 37 \\
C1D2 & 7.54 & 0.59 & 224 & 43 \\
C2D0 & 5.96 & 0.51 & 212 & 39 \\
C2D1 & 7.46 & 0.55 & 210 & 41 \\
C2D2 & 5.32 & 0.48 & 214 & 48 \\
\hline Note & $>5$ & $0,5-0,75$ & $>60$ & $21-40$ (medium) \\
& (very high) & (high) & (very high) & $41-60$ (high) \\
\hline
\end{tabular}

Source: The results of the soil analysis by BPTP Yogyakarta, 2017

\section{Plant height and the number of branches}

Table 3 shows that lighting duration had a significant effect $(P<0.01)$ on the plant height and the number of brahnces. Similarly,
Hermanto (2015) reported a significant difference $(\mathrm{P}<0.05)$ in the height between alfalfa under a lighting for $16 \mathrm{~h}$ and $12 \mathrm{~h}$ per day. However, the contrary result was found in the 
Table 3. The plant height $(\mathrm{cm})$, the number of the brahnces and the number of the leaves of the alfalfa in the second regrowth phase with the treatments of the lighting duration and the dolomite addition

\begin{tabular}{|c|c|c|c|c|}
\hline \multirow[b]{2}{*}{ Lighting Duration } & \multicolumn{4}{|c|}{ Dolomite Doses } \\
\hline & $\begin{array}{c}\text { D0 } \\
\text { (0 ton/ha) }\end{array}$ & $\begin{array}{c}\mathrm{D} 1 \\
\text { (6 tons/ha) } \\
\end{array}$ & $\begin{array}{c}\mathrm{D} 2 \\
\text { (12 tons/ha) }\end{array}$ & Mean \\
\hline \multicolumn{5}{|l|}{ Plant Height } \\
\hline C0 (12 hours) & $81.89 \pm 6.35$ & $72.22 \pm 8.48$ & $78.67 \pm 3.28$ & $77.59^{x} \pm 8.68$ \\
\hline C1 (14 hours) & $84.17 \pm 5.97$ & $78.00 \pm 4.73$ & $80.89 \pm 4.25$ & $81.02^{x} \pm 5.11$ \\
\hline C2 (16 hours) & $99.89 \pm 10.89$ & $88.55 \pm 9.23$ & $84.44 \pm 4.55$ & $90.96^{y} \pm 10.20$ \\
\hline Mean & $88.65^{b} \pm 10.99$ & $79.59^{\mathrm{a}} \pm 9.81$ & $81.33^{a} \pm 4.33$ & $(-)$ \\
\hline \multicolumn{5}{|c|}{ The Number of Branches } \\
\hline C0 (12 hours) & $31.57 \pm 4.20$ & $20.43 \pm 7.23$ & $31.73 \pm 5.32$ & $27.91^{y} \pm 7.48$ \\
\hline C1 (14 hours) & $27.50 \pm 4.78$ & $25.23 \pm 4.65$ & $20.33 \pm 1.53$ & $24.36^{x y} \pm 3.26$ \\
\hline C2 (16 hours) & $25.53 \pm 2.40$ & $21.67 \pm 1.46$ & $20.43 \pm 5.33$ & $22.54^{x} \pm 3.79$ \\
\hline Mean & $28.20^{b} \pm 4.32$ & $22.44^{\mathrm{a}} \pm 4.87$ & $24.17^{\mathrm{ab}} \pm 6.85$ & $(-)$ \\
\hline \multicolumn{5}{|c|}{ The Number of Leaves } \\
\hline CO (12 hours) & $473.67^{\mathrm{qr}} \pm 92.22$ & $497.67^{r s} \pm 63.36$ & $397.00^{\text {pqr }} \pm 67.51$ & $456.11 \pm 79.64$ \\
\hline C1 (14 hours) & $375.00^{\mathrm{pq}} \pm 31.24$ & $594.67^{\mathrm{s}} \pm 16.86$ & $346.00^{\mathrm{p}} \pm 68.11$ & $385.56 \pm 123.86$ \\
\hline C2 (16 hours) & $508.00^{\mathrm{qr}} \pm 17.52$ & $410.33^{\mathrm{pqr}} \pm 85.99$ & $341.33^{p} \pm 40.08$ & $419.89 \pm 87.10$ \\
\hline Mean & $452.22^{b} \pm 77.60$ & $500.89^{b} \pm 96.44$ & $361.44^{\mathrm{a}} \pm 58.44$ & $(+)$ \\
\hline
\end{tabular}

number of the branches of the alfalfa. Kurilcik et al. (2008) suggested that the length of stem shoot tended to increase with the addition of lighting duration (photoperiod) from 8 to 16 hours, and would decrease in the $24 \mathrm{~h}$ lighting duration. It was corroborated by the study of Torres and Roberto (2011) showing that the elongation of stem increased $38 \%$ with the increase in the photoperiod (the lighting duration) from 12 hours to 16 hours.

The results summarized in Table 3 showed that the dolomite addition had significant effect $(P<0.05)$ on the increase in the plant height. Similar result was also found in the number of branches. The plants without any dolomite addition were taller and had more brances than those with the dolomite addition. This unexpected result confirmed Hermanto (2015) that the biggest increase in the height of alfalfa was resulted from the treatment without any dolomite addition (0 ton/ha). Similar results were observed in the leaves. Domigues et al. (2016) suggested that calcification treatment (at certain concentration of calcium) was indicative of significant effect on the number of the leaves of the plant. Hao and Athanasios (2004) mentioned that the biomass of leaves would decrease with the increase in the $\mathrm{Mg}$ content of soil. The higher was the concentration of the $\mathrm{Mg}$ in the soil, the smaller the number of the leaves and the biomass of the leaves of the plants.

Rosmarkam and Yuwono (2002) corroborated the finding that high $\mathrm{CA}$ and $\mathrm{Mg}$ contents of soil caused the decrease in the absorption of kalium (K) and vice versa. Kalium is very important for growth, especially as the accelerator of the assimilate translocation from leaves to the storing organs (sink). Additionally, kalium is also involved in somata opening and closing process. The assimilate translocation would take place in the plants deficit of $\mathrm{K}$ in addition to the unbalanced stomata opening and closing process. It is related to photosynthesis process and glucose formation in plants. Mashud et al. (2013) stated that 
kalium deficit would cause the decrease in growth and production activities.

The results summarized in Table 3 showed zero correlation between the extending lighting duration as well as dolomite addition with the height and number of brances of alfalfa, but it is correlated with the number of leaves.

\section{The production of alfalfa plants}

The results summarized in Table 4 showed that dolomite addition had an insignificant effect $(P>0.05)$ on the increase of harvest weight and no correlation was found between the treatment of the lighting duration and the dolomite addition and the harvesting weight of the plants.

Sajimin et al. (2011) suggested that alfalfa plant could produce 34.31 to 50.25 gram/plant/harvest of fresh forage. Salisbury and Ross (1992) stated that the fresh weight of the plant was indicative of the metabolism activity of the plant and the fresh weight of the plant was affected by the water content of the tissue, the nutrient element and the metabolism and photosynthesis results of the plant.

\section{Dry matter and organic matter}

The results summarized in Table 5 showed that the difference in the treatment of the lighting duration did not have any significant effect $(P>0.05)$ on the dry matter and organic matter contents of the alfalfa plants. It was consistent with Torres and Roberto (2011) suggesting that photoperiod (lighting duration) did not have any significant effect on the dry weight (DW) of the plants. The organic matter in the study was within the normal range of NRC (2001), namely $11 \%$ ash content and $89 \%$ organic matter.

The dolomite addition could increase the dry matter content. Also, the addition of the lighting duration was correlated with the dolomite, but the addition of the light duration and the dolomite were not correlated with the organic matter (OM) in the second regrowth phase. Similarly, Domingues et al. (2016) reported that the treatment of the calcification (at certain calcium concentration) had a significant effect $(P<0.05)$ on the dry weight of the stem of the plant. Sajimin et al. (2011) stated that the dry weigh of alfalfa was in the range of 20.1 to $26.6 \%$ with the treatment of different fertilizers.

Table 4. The fresh weight of the alfalfa plant $(\mathrm{g})$ in the second regrowth phase with the treatment of the addition of the lighting duration and dolomite fertilizing

\begin{tabular}{|c|c|c|c|c|}
\hline \multirow[b]{2}{*}{ Lighting Duration } & \multicolumn{4}{|c|}{ Dolomite Doses } \\
\hline & $\begin{array}{c}\text { D0 } \\
\text { (0 ton/ha) }\end{array}$ & $\begin{array}{c}\mathrm{D} 1 \\
\text { (6 tons/ha) }\end{array}$ & $\begin{array}{c}\mathrm{D} 2 \\
\text { (12 tons/ha) }\end{array}$ & Mean \\
\hline \multicolumn{5}{|l|}{ Fresh Production } \\
\hline CO (12 hours) & $55.25 \pm 4.94$ & $46.38 \pm 12.94$ & $44.13 \pm 10.29$ & $55.25 \pm 4.94$ \\
\hline C1 (14 hours) & $44.50 \pm 10.93$ & $40.00 \pm 3.65$ & $40.25 \pm 13.57$ & $44.50 \pm 10.93$ \\
\hline C2 (16 hours) & $37.63 \pm 8.63$ & $33.63 \pm 2.53$ & $32.75 \pm 6.59$ & $37.63 \pm 8.63$ \\
\hline Mean $^{\text {s }}$ & $45.79 \pm 10.81$ & $40.00 \pm 9.38$ & $39.04 \pm 10.74$ & $45.79 \pm 10.81$ \\
\hline \multicolumn{5}{|l|}{ Production (DM) } \\
\hline 12 hours & $18.41 \pm 3.08$ & $15.78 \pm 3.96$ & $15.15 \pm 4.33$ & $16.45^{b} \pm 3.76$ \\
\hline 14 hours & $14.94 \pm 3.13$ & $12.89 \pm 1.17$ & $16.18 \pm 5.86$ & $14.67^{\mathrm{ab}} \pm 3.80$ \\
\hline 16 hours & $12.93 \pm 2.38$ & $11.84 \pm 1.57$ & $9.97 \pm 3.25$ & $11.58^{a} \pm 2.59$ \\
\hline Mean $^{\mathrm{s}}$ & $15.42 \pm 3.52$ & $13.50 \pm 2.89$ & $13.77 \pm 5.05$ & - \\
\hline
\end{tabular}


Table 5. The dry matter and organic matter contents of the alfalfa plant (\%) in the second regrowth phase with the treatments of the lighting duration and the dolomite fertilizing

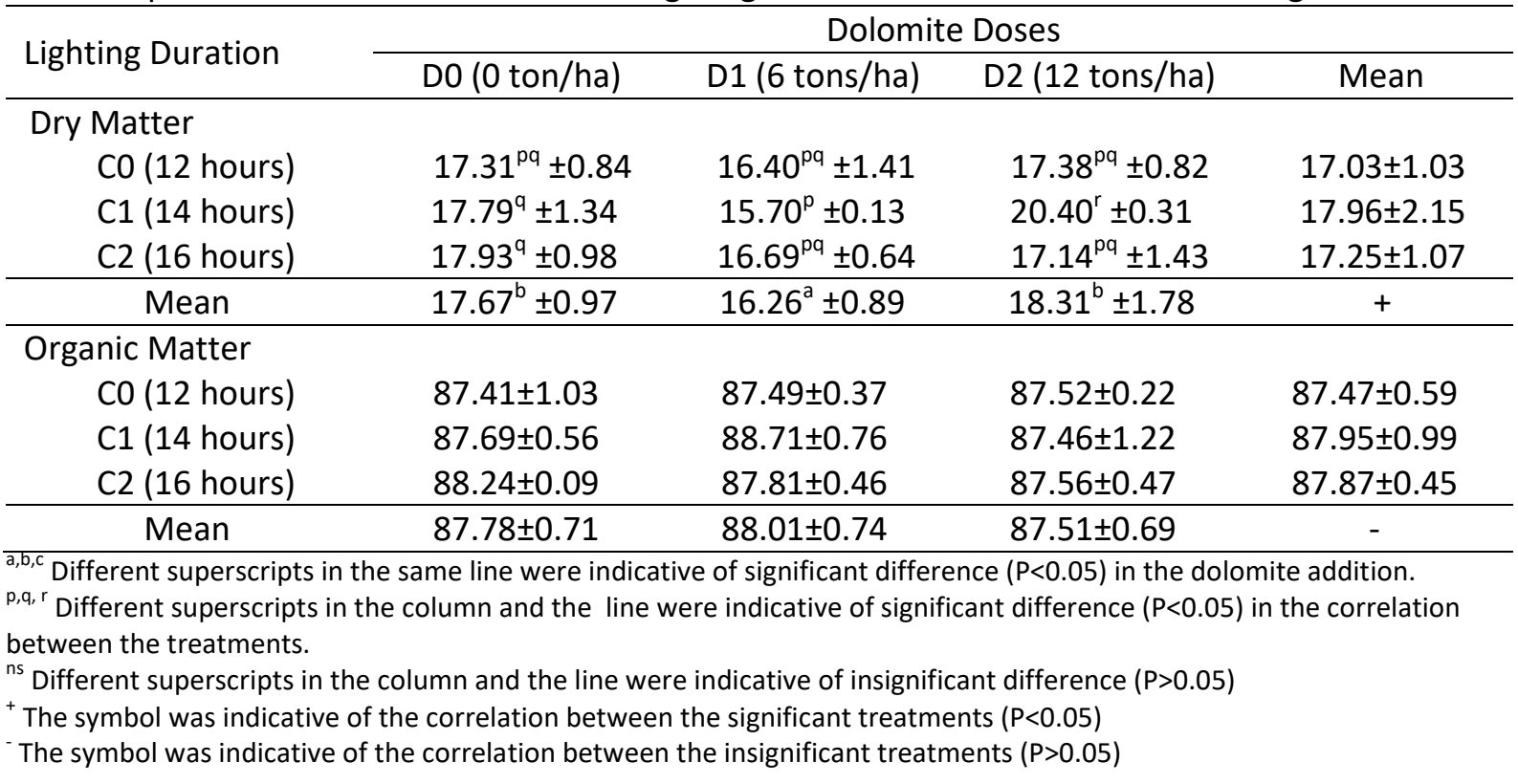

Magnesium is required in enzymatic activities and served as the central atom of chlorophyll. Magnesium activates the enzyme ribulose-1,5bisphosphate (RuBP) carboxylase that plays an important role in the photosyntesis process (Cakmak and Yazici, 2010; Gransee and Fuhrs, 2012; Yang et al., 2012). A continous addition of lighting could increase the photosynthesis process of plants. Buntoro et al. (2014) showed that light played an important role in the growth of cultivated plants, especially because of its role in photosynthesis process. The $\mathrm{Mg}$ element in the dolomite and good quality of lighting supported the photosynthesis of plants. Anni et al. (2013) informed that the plants with good photosynthesis would increase the dry weight yield of the plants.

\section{Conclusion}

The 16-hour lighting duration was the best for increasing the height of alfalfa plant, but it decreased the number of branches and the harvesting results (fresh weight and dry matter weight). The addition of the lighting duration did not have any significant effect on the number the leaves, the dry matter and the organic matter of the alfalfa plants.
The addition of 6 tons/ha dolomite was the best treatment to increase the number of the leaves of the alfalfa plants. Meanwhile, 12 tons/ha dolomite was best for increasing increase dry matter production of alfalfa plants.

The dolomite addition decreased the height and the number of branches of alfalfa plants. It did not significantly affect the fresh production, dry matter and organic matter of alfalfa plants. A significant correlation existed between the treatments of the lighting duration of 14 hours and the addition of 6 tons/ha dolomite (C1D1) and the number of leaves. Another significant correlation was observed between the treatments of the lighting duration of 14 hours and the addition of 12 tons/ha (C1D2) and the dry matter production.

\section{Acknowledgements}

The authors express their sincere gratitude to the Head of Forages and Pasture Science Laboratory, also Dean of the Faculty of Animal Science, Universitas Gadjah Mada for granting the permission to build a greenhouse specific for the tropical alfalfa seed research center. The authors also thank all alfalfa research team. 


\section{References}

Abdulwehab, S.A., S.A.F. El-Nagerabi and A.E. Elshafie. 2015. Leguminicolous Fungi Associated With Some Seeds of Sudanese Legumes. BIODIVERSITAS. Volume 16 (2) : 269-280.

AOAC. 2005. Official Method of Analysis 18th Edition. Association of Officiating Analytical Chemists. Washington DC.

Anni, I.A., S. Endang and S. Haryanti. 2013. Pengaruh naungan terhadap pertumbuhan dan produksi tanaman bawang daun (Allium fistulosum L.) di Bandungan, Jawa Tengah. Jurnal Biologi 2(3): 3140.

Buntoro, B.H., R. Rohlan and S. Trisnowati. 2014. Pengaruh takaran pupuk kandang dan intensitas cahaya terhadap pertumbuhan dan hasil temu putih (Curcuma zedoaria L.). Vegetalika 3(4): 2939.

Cakmak, I. and A. Yazici. 2010. Magnesium: A forgotten element in crop production. Better Crops 94: 23-25.

Cash, D. 2009. Alfalfa Management Guide For Ningxia. United Nations Food dan Agriculture Organization. Beijing.

Domingues, L.S., D.R. Nerineia, L.A. Jeronimo, T. Micheli, F.P. Della and E.M.Z. Allan. 2016. Growth, grain yield dan calcium, potassium dan magnesium accumulation in common bean plants as related to calcium nutrition. Acta Scientiarum 38(2): 207-217.

Fitter, A.H. and R.K.M. Hay. 1981. Environmental Physiologi of Plants. Academic Press, London. Alih bahasa oleh Sri Andari dan ED Purbayanti. 1991. Fisiologi Lingkungan Tanaman. Gadjah Mada University Press. Yogyakarta.

Gardner, F.P., R.B. Pearce and R.L. Mitchell. 1991. Fisiologi Tanaman Budidaya. Penerbit Universitas Indonesia. Jakarta.

Gransee, A. and A. Fuhrs. 2012. Magnesium mobility in soils as a challenge for soil dan plant analysis, magnesium fertilization dan root uptake under adverse growth conditions. Plant Soil 368: 5-21.

Hao, X. and P.P. Athanasios. 2004. Effect of calcium dan magnesium on plant growth, biomass partitioning, dan fruit yield of winter greenhouse tomato. Hort Science 39(3): 512-515.

Hermanto. 2016. Pengaruh berbagai dosis dolomit pada tanah regosol dan lama penyinaran terhadap produktivitas tanaman alfalfa (Medicago sativa L.). Tesis Program Magister Ilmu Peternakan. Fakultas Peternakan. Universitas Gadjah Mada. Yogyakarta.

Kurilcik, A., S. Dapkuniene, G. Kurilcik, S. Zilinskaite, A. Zukauskas and P. Duchovskis. 2008. Effect of photoperiod duration on the growth of Chrysanthemum plantlets in vitro. Scientific works of the Lithuanian Institute Of Horticulture 27(2): 39-46.

Mashud N., R.B. Maliangkay and M. Nur. 2013. Pengaruh pemupukan terhadap pertumbuhan vegetatif tanaman aren belum menghasilkan. Buletin Palma 14(1): 13-19.

National Research Council. 2001. Nutrient Requirements of Dairy Cattle, 7th rev, ed. National Academy Press, 2101 Constitution Avenue, N.W., Lockbox 285, Washington, D.C.

Olroff, S.B. and D.H. Putnam. 2007. Harvest Strategies for Alfalfa Irrigated Alfalfa Management. University of California Agriculture dan Natural Resources Publication, Oakland.

Rosmarkam, A. and N.W. Yuwono. 2002. IImu Kesuburan Tanah. Kanisius. Yogyakarta.

Sajimin. 2011. Medicago sativa L. (alfalfa) sebagai tanaman pakan ternak harapan di Indonesia. Balai Penelitian Ternak Bogor. Wartazoa 21(2): 91-98.

Salisbury, F.B. and C.W. Ross. 1992. Fisiologi Tumbuhan. Jilid I. Cetakan Keempat. Penerbit ITB, Bandung. (Diterjemahkan oleh: L. Sumaryono 1995).

Sarmita, S., E.D. Hastuti and S. Haryanti. 2011. Pertumbuhan legum pada ketinggian yang berbeda. Bioma 13(2): 67 - 72.

Smith, D.H., K.G. Beck, F.B. Pears and W.M. Brown. 2006. Alfalfa: Production dan Management. No.703. Colorado State University Cooperative Extension, Colorado.

Steel, R.G.D. and J.H. Torrie. 1995. Prinsip dan Prosedur Statistika Suatu Pendekatan Biometrik. PT. Gramedia Pustaka Utama, Jakarta.

Subantoro, R. 2009. Mengenal karakter tanaman alfalfa (Medicago sativa L.). Mediagro, 5(2): 5062.

Suwignyo, B., B. Suhartanto, C.T. Noviandi, N. Umami, N. Suseno, Hermanto and B.W.H.E. Prasetiyono. 2017. Generative plant characteristics alfalfa (Medicago sativa L.) on different levels of dolomite dan lighting duration. Proceeding of the 1st International Conference on Tropical Agriculture pp: 353-361.

Widyati, S., Sumarsono, S. Anwar and D.W. Widjajanto. 2012. Pertumbuhan alfalfa mutan tropis pada lama penyinaran yang berbeda. Buletin Sintesis 16(1): 10- 13.

Yang, G.H., L.T. Yang and H.X. Jiang. 2012. Physiological impacts of magnesium-deficiency in Citrus seedlings: photosynthesis, antioxidant system dan carbohydrates. Trees 26:1237-1250. 